traits under study were much more affected by breed than by halothane phenotype. Regarding breed differences, the results may be summarized as follows :

1 - The LW breed, free from Halothane sensitivity, exhibits a relatively slow pH fall and gives meat with the most satisfying technological qualities.

2 - The $\mathrm{P}$ breed combines a low $\mathrm{pH} 1$ (due to the high incidence of HP animals) with a rather low ultimate $\mathrm{pH}$ (presumably due to a slightly higher muscle glycolytic potential). Since the post-mortem acidification of muscle tissue takes place at a fast rate and has a relatively large extent, the meat from $\mathrm{P}$ pigs presents the worst technological qualities.

3 - In the BL breed, the unfavorable effects of halothane sensitivity are counterbalanced to some extent by the maintaining of ultimate $\mathrm{pH}$ at a higher level than in the two other breeds in most muscles studied : BL pigs are consequently intermediate between LW and $\mathrm{P}$ in meat quality.

\title{
Genetic parameters of some meat quality traits in the Large-White, French Landrace and Belgian Landrace pig breeds
}

\author{
G. COLE ${ }^{(1)}$, Geneviève LE HENAFF ${ }^{(2)}$, P. SELLIER ${ }^{(2)}$
}

(1) Department of Animal Science, Njala University College, Freetown, Sierra Leone (2) Institut National de la Recherche Agronomique, Station de Recherches de Génétique quantitative et appliquée, 78350 Jouy-en-Josas

This analysis deals with data collected between 1974 and 1986 in central progeny-test stations on 8867 Large-White (LW), 4098 French Landrace (FL) and 2840 Belgian Landrace (BL) female pigs, slaughtered at $100 \mathrm{~kg}$ liveweight. The meat quality traits involved in this study are : subjective score (SS), ultimate $\mathrm{pH}$ of the Adductor femoris muscle ( $\mathrm{pHu}$ ), reflectance of the Gluteus superficialis muscle (Ref), water holding capacity (imbibition time) of the Biceps femoris muscle (WHC) and meat quality index (MQI) combining $\mathrm{pHu}$, Ref and WHC and predicting the technological yield of cooked "Paris ham" processing. Meat quality traits are expressed as deviations from the "slaughter day" average whereas growth and body composition traits are expressed as deviations from the "batch" average. Heritabilities (h2) and genetic correlations (rA) are estimated from the sire variance and covariance components, separately for each breed (2483, 1123 and 493 sires in LW, FL and BL breeds, respectively). Genetic correlations between average daily gain (ADG) and meat quality traits are generally unfavorable in the LW breed (c.g. $\mathrm{rA}=-0.27 \pm 0.09$ for $\mathrm{SS}$ and $\mathrm{ADG}$, and $\mathrm{rA}=-0.32 \pm 0.13$ for MQI and ADG), whereas they are of much lower magnitude in the FL and the BL breeds. Genetic correlations between estimated carcass lean content (ECLC) and meat quality traits are mostly unfavorable : the genetic antagonism between meat quantity and meat quality appears to be stronger in the BL than in the LW breed (e.g. $\mathrm{rA}=-0.53 \pm 0.20$ vs $\mathrm{rA}=-0.32 \pm 0.08$ for SS and ECLC, and $\mathrm{rA}=-0.28 \pm 0.20$ vs $\mathrm{rA}=-0.16 \pm 0.10$ for MQI and ECLC).

\section{Lipids and qualities of pork adipose and muscular tissues. Factors of variation. 1rst Part : Lipids and qualities of adipose tissue. Factors of variation}

\author{
J.P. GIRARD ${ }^{(1)}$, Josiane BOUT ${ }^{(2)}$, Dominique SALORT ${ }^{(2)}$
}

(1) Institut National de la Recherche Agronomique, Station de Recherches sur la Viande, Theix 63122 Ceyrat

(2) Institut Technique du Porc, B.P. 3, 35650 Le Rheu

The three main components of fatty tissues are: water, proteins and lipids. The latter, because of their effect on quality, are generally divided, into glycerol fatty acid esters and the unsaponifiable fraction with pigments and steroids. 